\title{
Nutritional score of meat products at retail in Serbia
}

\author{
Mladen Rašeta ${ }^{*}$, Ivana Branković Lazićl, Boris Mrdovićl, Becskei Zsolt², Savić Mila², Mirjana Grubić3, \\ Jelena Jovanović ${ }^{1}$
}

A b s tra c t: Nutri-score is simplified front-of-pack nutrition labelling on packed food products, used in a broad international context to categorize food products into five colour/letter grades (best A to worst E) that reflect the foods' nutritional quality. The labels serve as potential help for consumers to make healthier food choices and encourage food industries to improve the nutritional quality of the foods they produce. The aim of this study was to determine the nutritional scores and grades of meat products present on the Serbian retail market. Ultimately, this should point out to consumers the importance of proper nutrition and encourage the meat industry to adapt to new labelling requirements. During a two year period, 310 packaged locally-produced meat products were purchased at retail, graded according to the Nutri-score method and categorized into 13 ad hoc product groups. The results obtained showed that $82.5 \%$ of all examined meat products had nutritional scores that meant they were classified as unhealthy foods, while only $2.9 \%$ of meat products (these were fresh meat or minced meats) were classified as healthy foods. Of the total number of examined meat products, $41.5 \%$ were classified as grade E, $41 \%$ were classified as grade D, $13 \%$ received grade $C, 1.6 \%$ received grade $B$, while only $2.9 \%$ were classified as grade A. Sodium chloride was an especially burdensome parameter in 10 groups (77\% of all products examined), while the presence of saturated fat was troublesome in 7 groups (54\%) and high energy balance in 2 groups (15\%). Serbian manufacturers are advised to implement new formulations and/or procedures in an effort to reduce these parameters in the meat products they produce.

Keywords: nutritional score, meat products, nutrition labelling, sodium chloride, healthy food.

\section{Introduction}

Novel national legislation (Anonymous, 2018) requires a nutrition declaration on meat products placed on the Serbian retail market. In the European Union, labelling of nutritional parameters has been mandatory since 2011 (Anonymous, 2011). In 2008, following an evaluation of the legislation on food labelling by the European Commission's DirectorateGeneral for Consumer and Health, the European Commission issued a proposal which would combine two major Directives (Directive 2000/13/EC1 and Directive 90/496/EEC2) into one Framework Regulation (Regulation 1169/2011) (Anonymous, $1990,2000,2011)$. Areas covered by the Regulation are, amongst others, nutrition information, origin labelling, legibility and allergen labelling. For prepacked foods, food business operators must have a nutrition declaration on their label, indicating the energy value and the amounts of fat, saturated fat, carbohydrate, sugar, protein and salt. The energy value and all nutrients declared must be expressed in absolute amounts per $100 \mathrm{~g}$ or $100 \mathrm{ml}$ (Anonymous,
2013). They can also be expressed per package or per portion. Information on vitamins and minerals must, in addition, be expressed as a percentage of the nutrient reference values (NRVs), which can also be given in graphic form (Anonymous, 2011c). From December 2016, food in the European Union had to be labelled with this nutritional data. Since the actual nutritional value of food can vary in relation to the declared value, it is important to define and specify the average nutritional value of the product (Knezevic and Rimac-Brncic, 2014). Consumer groups and public health organisations have called for bans on the advertising of "unhealthy" food to children for several decades. However, the definition of unhealthy has been a topic of considerable argument. Food companies have resisted having any products described as unhealthy, but have gradually developed a number of different schemes that define products they believe are 'healthy' (or at least 'healthier') and appropriate for advertising to children. Health and consumer groups have called for a single scheme - or nutrient profiling model consistent with international recommendations for

1 Institute of Meat Hygiene and Technology, Kacanskog 13, 11000 Belgrade, Republic of Serbia;

2University of Belgrade, Faculty of Veterinary Medicine, Bulevar Oslobodjenja 18, 11000 Belgrade, Republic of Serbia;

${ }^{3}$ Premium chicken d.o.o. Topolovacki put bb, 23210 Zitiste, Republic of Serbia.

${ }^{*}$ Corresponding author: Mladen Rašeta, mladen.raseta@inmes.rs 


\section{NUTRI-SCORE}

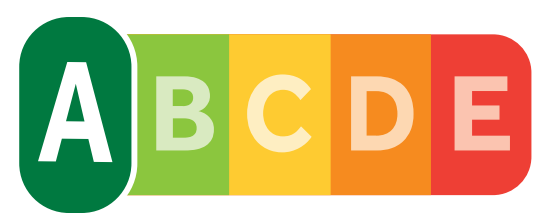

NUTRI-SCORE

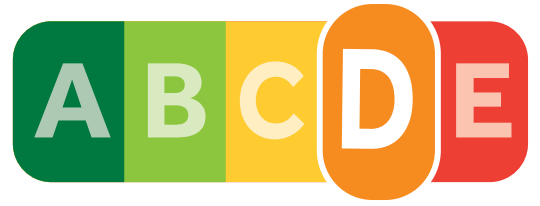

Figure 1. Nutri-score nutrition labelling scheme on the front food label at retail

preventing chronic disease and with national foodbased dietary guidelines. Ideally, this is a simple system which could be applied to all products and with a clearly defined cut-off for defining which foods are not suitable for advertising to children (Rayner and Scarborough, 2009).

Front-of-pack nutrition labels are designed to help consumers evaluate the healthiness of foods and to promote healthier food choices (Hagmann and Siegrist, 2020). Since the beginning of the $20^{\text {th }}$ century, the rise of unhealthy dietary habits has been a trend in many countries (WHO, 2003). Much of the disease burden worldwide, including cancers, cardiovascular disease and diabetes, could be reduced if people changed their behaviours, e.g. stopped smoking, reduced their alcohol intake, ate healthier diets and became more physically active (Diepeveen et al., 2013). Policy makers have a variety of means at their disposal by which they can try to influence these behaviours, ranging from the provision of information to the public, through to measures that restrict choice by regulation (Anonymous, 2007).

The Nutri-score label is based on the United Kingdom (UK) Food Standards Agency's nutrient profiling system (NPS; original version: FSANPS, 2011), which evaluates the overall healthiness of a food product according to its nutritional composition (Anonymous, 2011b). The FSA-NPS was built with a perspective of preventing a large range of chronic diseases. It allocates a score to a given food/beverage from its content (per $100 \mathrm{~g}$ or $100 \mathrm{ml}$ ) of energy, saturated fat, sugar, sodium, dietary fibre, protein and fruit/vegetables/legumes/nuts. The model applies equally to all food and drink, there are no exemptions or category-specific criteria, and a judgment can be made as to whether the food should be placed under advertising restrictions (Anonymous, 2011a). It was initially developed and validated in the UK, where it has been used for advertising regulation (Arambepola et al., 2008) and was transposed in France as FSAm-NPS (Julia et al., 2014). To classify healthiness, the product's content of several health-promoting (fruit, vegetables and nuts, fibre and protein) and critical nutrients (energy, saturated fat, total sugar and sodium) is evaluated. This results in a single NPS, which is then transformed into a colour-coded letter-based grade that is simple for consumers to understand (Figure 1). Studies of the NPS underlying Nutri-score, and comparative studies of the perception, understanding and use of various strategies for front-of-pack labelling, done between 2014 and 2017, concluded that the Nutri-score was superior to other formats (Julia and Hercberg, 2017). The scientific evidence weighted heavily in the decision by health authorities to adopt the Nutriscore in France (Julia et al., 2018).

Consumption of more food with higher FSAmNPS Dietary Index (DI) scores, reflecting a lower nutritional quality of the food consumed, was associated with an increased risk of cancer (colo-rectal, upper aerodigestive tract and stomach, liver, and lung in men and breast in women) (Deschasaux et $a l, 2019)$. A nutritional scoring system is helpful to consumers, because it encourages them to decide to purchase more adequately healthy foods (in Nutriscore, foods with these scores are graded as A or B). Consumption of food products with worse nutritional grades (D or E) was associated with a higher risk of development of chronic diseases and cancer in a large multinational European cohort. Since 31 October 2017, the Nutri-score front-of-pack labelling system (a synthetic information system based on colours and letters from green/A to red/E), allowing consumers to see and compare at a glance the nutritional value of pre-packaged foods, has been implemented on a voluntary basis in France (Anonymous, 2017).

\section{Materials and Methods}

A total of 310 packaged meat products, locally produced in Serbia and sold on the Serbian retail market, were examined over a period of two years. Meat products were in their original packaging, 
taken from retail, and were classified by us into 13 ad hoc groups:

1. Boiled sausages finely ground

2. Boiled sausages coarsely ground

3. Boiled sausages with meat pieces

4. Cooked sausages and pâtés

5. Canned minced meat

6. Canned meat chunks

7. Smoked meat products

8. Dried meat products

9. Dried and semi-dried fermented sausages

10. Meat dishes and dishes with meat

11. Bacon and crackling

12. Meat preparations

13. Fresh meat and minced meat.

The sampled meat products, meat preparations and fresh meat were originally from domestic producers. On the basis of the information given in the nutrition declaration, the meat products were scored according to Nutrient Profiling Technical Guidance (Anonymous, 2011a).

In brief, the model uses a simple scoring system where points are allocated on the basis of the nutrient content of $100 \mathrm{~g}$ of a food or drink. Points were awarded for category A nutrients (energy, saturated fat, total sugar and sodium; Table 1) and for category $\mathrm{C}$ nutrients (fruit, vegetable and nut content, fibre and protein; Table 2). The score for category $\mathrm{C}$ nutrients was the subtracted from the score for category A nutrients to give the final nutrient score. Fibre content was calculated as shown in generic Table 2, using the AOAC reference method.

For category A nutrients, a maximum of ten points can be awarded for each nutrient. For category $\mathrm{C}$ nutrients, a maximum of five points can be awarded for each nutrient/food component. After obtaining the final nutrition scores, the values were compared with the cut-off values for the colour-coded food grades A to E (Table 3).

Table 1. Class A nutrient point scores, depending on the amount of each nutrient in $100 \mathrm{~g}$ or $100 \mathrm{ml}$ of a food or drink

\begin{tabular}{ccccc}
\hline Points & Energy $(\mathbf{k J})$ & Saturated Fat $(\mathbf{g})$ & Total Sugar $(\mathbf{g})$ & Sodium $(\mathbf{m g})$ \\
\hline 0 & $\leq 335$ & $\leq 1$ & $\leq 4.5$ & $\leq 90$ \\
1 & $>335$ & $>1$ & $>4.5$ & $>90$ \\
2 & $>670$ & $>2$ & $>9$ & $>180$ \\
3 & $>1005$ & $>3$ & $>13.5$ & $>270$ \\
4 & $>1340$ & $>4$ & $>18$ & $>360$ \\
5 & $>1675$ & $>6$ & $>22.5$ & $>450$ \\
6 & $>2010$ & $>7$ & $>31$ & $>540$ \\
7 & $>2345$ & $>8$ & $>36$ & $>630$ \\
8 & $>2680$ & $>9$ & $>40$ & $>720$ \\
9 & $>3015$ & $>10$ & $>45$ & $>810$ \\
10 & $>3350$ & & & $>900$ \\
\hline
\end{tabular}

Table 2. Class C nutrient point scores, depending on the amount of each nutrient in $100 \mathrm{~g}$ or $100 \mathrm{ml}$ of a food or drink

\begin{tabular}{ccccc}
\hline Points & $\begin{array}{c}\text { Fruit, vegetables, } \\
\text { nuts (\%) }\end{array}$ & $\begin{array}{c}\text { Fibre (g), measured as } \\
\text { non-starch polysaccharides }\end{array}$ & $\begin{array}{c}\text { Fibre (g), measured by } \\
\text { the AOAC } \text { method }\end{array}$ & Protein (g) \\
\hline 0 & $\leq 40$ & $\leq 0.7$ & $\leq 0.9$ & $\leq 1.6$ \\
1 & $>40$ & $>0.7$ & $>0.9$ & $>1.6$ \\
2 & $>60$ & $>1.4$ & $>1.9$ & $>3.2$ \\
3 & - & $>2.1$ & $>2.8$ & $>4.8$ \\
4 & - & $>2.8$ & $>4.7$ & $>6.4$ \\
5 & $>80$ & $>3.5$ & & $>8.0$ \\
\hline
\end{tabular}

a American Association of Oil Chemists 
Table 3. Limit values of the nutritional score for determining the color-based grade to which a food belongs

\begin{tabular}{|ccc|}
\hline $\begin{array}{c}\text { Total nutritional score for solid } \\
\text { foods }\end{array}$ & $\begin{array}{c}\text { Total nutritional score for } \\
\text { liquid foods }\end{array}$ & Colour and matching letter \\
\hline To-1 & 0 & Dark green - A \\
\hline $0-2$ & Minimum 1 & Light green - B \\
\hline $3-10$ & $2-5$ & Yellow - C \\
\hline $11-18$ & $6-9$ & Light orange - D \\
\hline 19 and more & 10 and more & Dark orange - E \\
\hline
\end{tabular}

Source: Nutri-score — The front of pack nutrition labelling scheme recommended in France (https://ec.europa.eu/food/sites/food/files/ animals/docs/comm_ahac_20180423_pres4.pdf)

If a food or drink scores 11 or more category A points, then it cannot score points for protein unless it also scores 5 points for fruit, vegetables and nuts. A food is classified as less healthy if it scores 4 points or more. Therefore, in terms of the presence of nutrients in $100 \mathrm{~g}$ or $100 \mathrm{ml}$, foods that are labelled green (A or B) are considered to be of better health quality, while foods that are labelled orange (D or E) are of lower health quality.

\section{Results}

Grouped results of the colour-coded food grades achieved by locally-produced meat products on the Serbian retail market are presented in Table 4.

The results showed that $82.5 \%$ of all examined meat products were classified as unhealthy foods, while only $2.9 \%$ of the meat products (and these were fresh meats and minced meats) were classified as healthy foods.

Table 4. Number of meat products in each nutritional grade for groups of meat products available at retail level in Serbia

\begin{tabular}{|c|c|c|c|c|c|c|}
\hline \multirow{2}{*}{ Meat product group } & \multirow{2}{*}{$\begin{array}{l}\text { Number of samples } \\
\text { examined }\end{array}$} & \multicolumn{5}{|c|}{ Nutritional grade } \\
\hline & & $\mathbf{A}$ & B & $\mathbf{C}$ & $\mathbf{D}$ & $\mathbf{E}$ \\
\hline Boiled sausages, finely ground & 30 & & & & 20 & 10 \\
\hline Boiled sausages, coarsely ground & 30 & & & & 8 & 22 \\
\hline Boiled sausages with meat pieces & 20 & & & 5 & 15 & \\
\hline Canned minced meat & 20 & & & 5 & 12 & 3 \\
\hline Canned meat chunks & 30 & & & 11 & 19 & \\
\hline Smoked meat products & 30 & & 2 & 7 & 19 & 2 \\
\hline Dried meat products & 20 & & & & 10 & 10 \\
\hline Dried and semi-dried fermented sausages & 30 & & & & & 30 \\
\hline Pâté and cooked sausages & 20 & & & 1 & 12 & 7 \\
\hline Meat dishes and dishes with meat & 20 & 1 & 1 & 9 & 8 & 1 \\
\hline Bacon and cracklings & 30 & & & & & 30 \\
\hline Meat preparations & 20 & & & 2 & 4 & 14 \\
\hline Fresh meat and minced meats & 10 & 8 & 2 & & & \\
\hline Total & 310 & 9 & 5 & 40 & 127 & 129 \\
\hline$\%$ & 100 & 2.9 & 1.6 & 13 & 41 & 41.5 \\
\hline
\end{tabular}


Table 5. Particularly burdensome nutritional parameters found in meat products available at retail in Serbia

\begin{tabular}{ll}
\hline Meat product group & Particularly burdensome nutritional parameters \\
\hline Boiled sausages finely ground & Sodium chloride, saturated fat \\
Boiled sausages coarsely ground & Sodium chloride, saturated fat \\
Boiled sausages with meat pieces & Sodium chloride \\
Canned minced meat & Sodium chloride, saturated fat \\
Canned meat chunks & Sodium chloride \\
Smoked meat products & Sodium chloride \\
Dried meat products & Sodium chloride \\
Dried and semi-dried fermented sausages & Saturated fat, sodium chloride, energy \\
Pâté and cooked sausages & Saturated fat \\
Meat dishes and dishes with meat & Sodium chloride \\
Bacon and cracklings & Saturated fat, energy \\
Meat preparations & Saturated fat, sodium chloride \\
Fresh meat and minced meats & None detected \\
\hline
\end{tabular}

Particularly burdensome nutritional parameters that led to the classification of meat products as unhealthy food are presented in Table 5.

Particularly burdensome parameters significantly contributed to the formation of the final assessment of nutritional scores (data not shown) for meat products. For the 13 groups of examined meat products for which the nutritional score was determined, sodium/sodium chloride was an especially burdensome parameter in 10 groups $(77 \%)$, while the presence of saturated fat was troublesome in 7 groups (54\%) and a high energy balance in 2 groups $(15 \%)$.

\section{Discussion}

Analysis of the nutritional score for meat products on the Serbian retail market shows that $82.5 \%$ of all examined meat products were classified as unhealthy foods, while only $2.9 \%$ of the meat products (and these were fresh meats or minced meats) were classified as healthy foods. Especially burdensome parameters for the nutritional scores were sodium chloride $(77 \%)$, saturated fat (54\%) and high energy balances (15\%). Reasons for this classification of meat products as mostly unhealthy can lie in the nature of the foods themselves, if these are not intended to be consumed in quantities as large as $100 \mathrm{~g}$ per day (bacon, dried meat products, fermented sausages, pâté). However, for other meat products examined, recipe corrections will be needed in order to reduce burdensome nutrients. First of all, the need to reduce sodium in meat products is evident, as many groups of meat products were classified as unhealthy foods precisely because of their high sodium content (boiled sausages, canned minced meat and meat chunks, smoked meat products, dried meat products, fermented sausages, meat dishes and meat preparations). A previous market study in Serbia also reported the need to reduce sodium in many groups of meat products (Lilic et al., 2017).

Among the additives used in the production of meat products, kitchen salt (sodium chloride) is the most commonly used, giving a desirable taste, improved texture and prolonged shelf-life. Salt is added to meat products primarily to produce the characteristic, necessary salty taste of meat products. The degree of sensory perception of salt depends not only on the percentage/ratio of salt to other product components, but also on the degree of hydration and quantity of water (Raseta et al., 2013). Although sodium chloride is a very important food ingredient, it is commonly found in large quantities (\%) in meat products $(1.2-1.8 \%$ in cooked sausages, $1.8-2.2 \%$ in both finely and coarsely ground boiled sausages, $1.2-2.5 \%$ in canned minced meat, $2.4-3.0 \%$ in fermented sausages and $3.0-5.0 \%$ in dried meat products) (Vukovic, 2012). Daily consumption of meat products with high levels of sodium invokes increased blood pressure and consequent cardiovascular disorders in consumers. Therefore, there is an intense effort to reduce consumers' daily sodium intake (Lazic et al., 2015). 
Saturated fat content was also a burdensome nutritional score parameter for $54 \%$ of our examined meat products, together with a high energy balance $(15 \%)$. Daily energy intake from saturated fat should be in the range of $5-10 \%$ of all-body energy needs, while trans fatty acids (industrial and those occurring naturally in food) should contribute $<1 \%$ of total daily energy needs (Spajic, 2020). Eating habits and nutritional values of foods play key roles in the prevention of major chronic degenerative diseases (Kant, 2010). Helping consumers make healthier food choices is a key issue for the prevention of cancer and other diseases. In many countries, authorities are considering implementing a simplified labelling system to reflect the nutritional quality of food products. However, although it would comply with the European Union labelling regulations, appending the Nutri-score on food product labels remains optional and, therefore, relies on voluntary uptake by food manufacturers (Deschasaux et al., 2018). Nonetheless, a unique nutritional labelling system for all EU countries is expected to be implemented in the future (Deschasaux et al., 2018).

\section{Conclusion}

The domestic meat industry in Serbia needs to make special, focused efforts to optimize the production of meat products, since $82.5 \%$ of the retail meat products were classified as unhealthy by the Nutri-score method. In doing so, the specifics of the type of meat product could be taken into account for some products (crackling, bacon, dried meat products, fermented sausages and pâté) that are not intended to be consumed in amounts as large as 100 $\mathrm{g}$ per day. Nonetheless, it is necessary to determine the nutritional score for every food based on the 100 $\mathrm{g}$ or $\mathrm{ml}$ set amount to enable consumers to compare different foods and improve their own food choices.

For meat products that have potential for nutritional score optimization (meat preparations, meat dishes, canned minced meat, canned meat chunks, boiled and cooked sausages), producers are advised to pay special attention to reducing levels of the particularly burdensome nutritional parameters, i.e., sodium chloride/sodium, saturated fat and the overall energy balance.

\title{
Nutritivni skor proizvoda od mesa na domaćem tržištu
}

\author{
Mladen Rašeta, Ivana Branković Lazić, Boris Mrdović, Becskei Zsolt, Savić Mila, Jelena Jovanović
}

A p s t r a k t: Nutritivni skor je pojednostavljeni sistem obeležavanja nutritivnog kvaliteta proizvoda od mesa, koji ih svrstava u pet kategorija sa odgovorajućom bojom i slovnom oznakom. Na ovaj način potrošači dobijaju dodatnu informaciju o nutritivnim svojstvima proizvoda od mesa koje kupuju, dok industrija dobija podsticaj da razvija kvalitetnije proizvode. Tokom dve godine ispitano je 310 uzoraka, od kojih je $82.5 \%$ klasifikovano kao ,,nezdravo” dok je samo $2.9 \%$ uzoraka koji su se odnosili na sveže i ustinjeno meso klasifikovani kao „zdravi”. Nutritivni skor proizvoda od mesa je pokazao da $41.5 \%$ proizvoda od mesa imaju ocenu E, 41\% ocenu D, $13 \%$ ocenu C, $1.6 \%$ ocenu B, dok je svega $2.9 \%$ dobilo ocenu A. Posebno opterécujući nutritivni parametar za proizvode od mesa je visok procenat soli natrijuma (77\%), zatim prisustvo zasićenih masti (54\%) i visok energetski bilans (15\%). Cilj ovog rada je da utvrđivanjem nutritivnog skora proizvoda od mesa potrošačima na domaćem tržištu ukaže na značaj adekvatnog izbora proizvoda od mesa sa aspekta nutritivnog kvaliteta, dok sa druge strane takve zahteve predoči industriji mesa.

Ključne reči: nutritivni skor, proizvodi od mesa, deklarisanje hrane, so, zdrava hrana.

Disclosure statement: No potential conflict of interest was reported by authors.

Acknowledgements: This study was funded by grants TR 31083 and III 46009 from the Ministry of Education, Science and Technological Development, Republic of Serbia. 


\section{References}

Anonymous (2018). Rulebook on the declaration, labeling and advertising of food. Official Gazette of the Republic of Serbia, 19/2017 and 16/2018.

Anonymous (2017). Journal Officiel de la République Française. Arrêté du 31 octobre 2017 fixant la forme de présentation complémentaire à la déclaration nutritionnelle recommandée par l'Etat en application des articles L. 3232-8 et R. 3232-7 du code de la santé publique. 2017. https://www.legifrance.gouv.fr/eli/arrete/2017/10/31/ SSAP1730474A/jo/texte

Anonymous (2013). Guidance on the Provision of Food Information to Consumers, September 2013, Regulation (EU) No. 1169/2011 https://www.fooddrinkeurope.eu/uploads/ publications documents/FDE_Guidance WEB.pdf

Anonymous (2011). Commission regulation(EU) No 1169/2011 of 25 October 2011. Regulation on food information provided to the consumer.

Anonymous (2011a). Nutrient Profiling Technical Guidance, Department of Health UK, http://www.dh.gov.uk/publications

Anonymous (2011b). Food Standards Agency. (2011). Nutrient Profiling Technical Guidance. Retrieved from https:// www.gov.uk/government/publications/the-nutrient-profiling-model

Anonymous (2011c). European Product Labelling Guide, Network enterprise Scotland http://www.enterprise-europescotland.com/sct/assets/documents/uploaded/general/ Product\%20Labelling\%20Guide.pdf

Anonymous (2007). Nuffield Council on Bioethics: Policy process and practice. In Public Health: ethical issues. London: Nuffield Council on Bioethics; 2007 http://www. nuffieldbioethics.org/sites/default/files/Public\%20 health\%20-20ethical\%20issues.pdf

Anonymous (2000). Directive 2000/13/EC of the European Parliament and of the Council of 20 March 2000 on the approximation of the laws of the Member States relating to the labelling, presentation and advertising of foodstuffs

Anonymous (1990). Directive 90/496/EEC of 24 September 1990 on nutrition labelling for foodstuffs

Arambepola, C., Scarborough, P. \& Rayner, M. (2008). Validating a nutrient profile model. Public Health Nutrition, 11, 371-378. https://doi.org/10.1017/S1368980007000377

Chauliac, D. M. The front of pack nutrition labelling scheme recommended in France. 12, https://ec.europa.eu/food/ sites/food/files/animals/docs/comm ahac 20180423 pres4.pdf

Deschasaux, M., Huybrechts, I., Murphy, N., Julia, C., Hercberg, S., Srour, B., Kesse-Guyot, E., Latino-Martel, P., Biessy, C., Casagrande, C., Jenab, M., Ward, H., Weiderpass, E., Ferrari, P., Riboli, E., Gunter, M. \& Touvier, M. (2019). Qualité nutritionnelle des aliments définie par le score FSAm-NPS sous-tendant le logo Nutri-Score et risque de cancer en Europe: Résultats de la cohorte EPIC. Nutrition Clinique et Métabolisme, 33(1), 8. https://doi.org/10.1016/j.nupar.2019.01.229

Deschasaux, M., Huybrechts, I., Murphy, N., Julia, C., Hercberg, S., Srour, B., Kesse-Guyot, E., Latino-Martel, P., Biessy, C., Casagrande, C., Jenab, M., Ward, H., Weiderpass E., Dahm, C. C., Overvad, K., Kyro, C., Olsen, A., Affret, A., Boutron-Ruault, M. C., Mahamat-Saleh,
Y., Kaaks, R., Kühn, T., Boeing, H., Schwingshackl, L., Bamia, C., Peppa, E., Trichopoulou, A., Masala, G., Krogh, V., Panico, S., Tumino, R., Sacerdote, C., Bueno-de-Mesquita, B., Peeters, P. H., Hjartåker, A., Rylander, C., Skeie, G., Ramón Quirós, J., Jakszyn, P., Salamanca-Fernández, E., Huerta, J. M., Ardanaz, E., Amiano, P., Ericson, U., Sonestedt, E., Huseinovic, E., Johansson, I., Khaw, K. T., Wareham, N., Bradbury, K. E., Perez-Cornago, A., Tsilidis, K. K., Ferrari, P, Riboli, E., Gunter M. J. \& Touvier, M. (2018). Nutritional quality of food as represented by the FSAm-NPS nutrient profiling system underlying the Nutri-Score label and cancer risk in Europe: Results from the EPIC prospective cohort study. PLOS Medicine, 15(9), e1002651. https:// doi.org/10.1371/journal.pmed.1002651

Diepeveen, S., Ling, T., Suhrcke, M., Roland, M., \& Marteau, T. M. (2013). Public acceptability of government intervention to change health-related behaviours: A systematic review and narrative synthesis. BMC Public Health, 13(1), 756. https://doi.org/10.1186/1471-2458-13-756

Hagmann, D. \& Siegrist, M. (2020). Nutri-Score, multiple traffic light and incomplete nutrition labelling on food packages: Effects on consumers' accuracy in identifying healthier snack options. Food Quality and Preference, 83, 103894. https://doi.org/10.1016/j.foodqual.2020.103894

Julia, C. \& Hercberg, S. (2017). Development of a new frontof-pack nutrition label in France: the five-colour NutriScore. Public Health Panorama, 3, 712-25.

Julia, C., Etilé, F. \& Hercberg, S. (2018). Front-of-pack NutriScore labelling in France: An evidence-based policy. The Lancet Public Health, 3(4), e164. https://doi.org/10.1016/ $\underline{\text { S2468-2667(18)30009-4 }}$

Julia, C., Kesse-Guyot, E., Touvier, M., Mejean, C., Fezeu, L. \& Hercberg S. (2014). Application of the British Food Standards Agency nutrient profiling system in a French food composition database. British Journal of Nutrition, 112, 1699-1705, https://doi.org/10.1017/ $\underline{\mathrm{S} 0007114514002761}$

Kant, A. K. (2010). Dietary patterns: biomarkers and chronic disease risk. Applied Physiology, Nutrition, and Metabolism, 35(2) 199-206.

Knezevic, N. \& Brncic, S. R. (2014). Oznacavanje hranjive vrijednosti na deklaraciji pehrambenih proizvoda. Croatian Journal of Food Technology, Biotechnology and Nutrition, 9 (1-2), 17-25.

Lazic, I. B., Raseta, M., Nikolic, D., Lukic, M., Karan, D. \& Lilic, S. (2015). Reducing the Sodium Chloride Content in Chicken Pate by Using Potassium and Ammonium Chloride. Procedia Food Science, 5, 22-25. https://doi. org/10.1016/j.profoo.2015.09.006

Lilic, S., Karan, D., Jovanovic, J., Babic, J., Borovic, B., Stefanovic, S. \& Raseta, M. (2017). Possibility of partial replacement of sodium chloride with potassium chloride to ammonium chloride in production of meatballs in tomato souce. Meat Technology 58(1), 47-51.

Raseta, M., Lazic, I.B., Vranic, D., Trbovic, D., Turubatovic, L., Jovanovic, J. \& Lilic, S. (2015). Salt content of poultry meat products. Proceedings International 57th Meat Industry Conference, Meat and meat products - perspectives of sustainable production, June 10th-12th, Belgrade, Serbia, pp 230-233 
Pongutta S., Chongwatpol P., Tantayapirak P. \& Vandevijvere S. (2018). Declaration of nutrition information on and nutritional quality of Thai ready-to-eat packaged food products. Public Health Nutrition, 21(8), 1409-1417

Rayner, M., \& Scarborough, P. (2009). The UK Ofcom Nutrient Profiling Model. 11. https://www.ndph.ox.ac.uk/cpnp/ files/about/uk-ofcom-nutrient-profile-model.pdf

Spajic, G. D. (2020). Strategies to achieve a healthy diet and health: reduction of trans fat and saturated fatty acids, Chapter 4. Agri-Food Industry Strategies for Healthy
Diets and Sustainability - New Challenges in $\mathrm{Nu}$ trition and Public Health, Pages 103-121. https://doi. org/10.1016/B978-0-12-817226-1.00004-7

Vukovic, I. (2012). Osnove tehnologije mesa, Veterinarska komora Srbije 4. izdanje, 125-126.

WHO. (2003). Diet, nutrition and the prevention of chronic diseases. Report of the joint WHO/FAO expert consultation. WHO Technical Report Series 916 (TRS 916). Geneva: World Health Organization.

Paper received: April $7^{\text {th }} 2020$.

Paper corrected: May $12^{\text {th }} 2020$.

Paper accepted: May $12^{\text {th }} 2020$. 